\title{
교육적 관점에서 바라본 BLG 구상의 의미
}

목차

I. 들어가면서

제 III장

II. 지속발전목표와 교육개발

III. BLG 구상 내용과 의미

1. BLG의 제안 배경 및 의미

2. 교육적 개발을 위한 BLG 구상의 의미

IV. 개발도상국 여아 교육을 위한 중앙아시아협회(CAI)의 사례와 사업의 원칙

1. 파키스탄의 사회문화적 맥락

2. 파키스탄의 교육과 여아교육의 실제

3. CAl와 교육사업

4. $\mathrm{CAI}$ 의 교육사업 원칙과 $\mathrm{BLG}$ 구상에의 함의

$\mathrm{V}$. 결론

참고문헌 


\section{I. 들어가면서}

2015년 9월 28일 한국정부는 UN 개발정상회의에서 지속가능개발목표(Sustainable Development Goals, 이하 SDGs)를 위한 국가적 기여방안의 하나로, '소녀들의 보다 나은 삶(Better Life for Girls, 이하 BLG)'을 발표하였다. 이 의제의 내용은 올해부터 향후 5 년 동안 국제사회의 여아, 여학생 및 여성 청소년들의 삶의 질을 증진하도록 하기 위하여 2 억 불 규모의 개발원조를 추진하 겠다는 것이었다. 국제개발협력에 있어 성평등 이슈는 핵심적인 개발목표였으며, 각 사업을 추진 하는데 있어 범분야 개발전략으로 인식되어 왔다. 그러나 여전히 개발선진국을 비롯하여 개발도 상국의 성평등 이슈는 아직도 해결해야 할 과제들이 쌓여있다. 성평등 이슈는 단지 생물학적 차 이를 넘어서서 오랫동안의 사회, 정치, 문화적인 차별로 자리잡아 왔고, 종국적으로 이들의 사회 경제적 수준과 삶의 질에 큰 영향을 미치고 있다. 특히 성인으로서 여성들의 삶에 부여할 수 있 는 도전적인 기회 이전에 유아, 아동기부터 평등한 사회참여 및 선택기회의 폭을 넓힐 수 있는 포괄적인 지원과 전략적 지원이 요구된다. 특정한 공동체가 오랫동안 유지해 온 사회, 정치, 문화 적인 요인이자 결과인 성차별 이슈를 해결하는 것은 단기간에 이루어질 수 있는 것은 아니지만, 적어도 이에 대한 관심 및 집중적인 지원과 성과를 향한 노력은 보다 평등한 삶을 양성에게 누릴 수 있도록 하는 중요한 발걸음이 될 것이다. 따라서 한국정부가 제안한 개발도상국 소녀들을 위 한 지원방안은 국제사회의 논의 흐름과 부합할 뿐만 아니라 보다 본질적인 변혁의 계기를 만들 수 있는 시도라고 보여진다.

그러나 당장 개발도상국의 여아 및 여성 청소년들을 위하여 무엇을 어떻게 지원하는 것이 가장 적절한 방법이고 또 이러한 방안을 실현하기 위한 전략은 무엇이어야 하는지에 대해서는 쉽게 이 야기하기 어렵다. 한국의 경우 다른 개발선진국에 비하여 훨씬 빠른 시기동안 근대적 개발이 진 행되어 왔고, 그에 따른 성평등 논의가 사회정치적으로 진행되어 왔다. 한국정부가 BLG를 통하 여 추진하고자 관심 갖는 영역으로 교육과 보건 이슈가 강조되고 있는 상황을 염두에 둔다면, 한 국 사회에서의 성평등 이슈는 큰 진전을 이루었다고 해도 된다. 적어도 공교육단계에서의 교육기 회에서 성차별적 요소는 거의 사라졌고, 공공보건 정책에서 성별 차이에 따른 지원을 원칙적으로 취하고 있기 때문이다. 물론 원칙적인 정책기조가 어떻게 현실적으로 잘 실현되고 있는가는 다른 문제이다. 또한 한국의 성평등 문제가 개발선진국의 수준에 이르렀다고 이야기할 수 없으며, 여전 히 사회, 정치, 경제, 문화적인 영역에서 차별적인 요소들이 남아있다는 점을 인정해야 한다. 즉, 한국의 사례가 국제사회의 중요한 기준이 될만한 경험과 전문성을 갖추고 있는가에 대해서는 확 신하기 어렵다는 말이다. 무엇보다도 성평등을 개발의 중요한 목표이자 전략으로 취하는 이유는 인간의 타고난 생물학적 차이로 인하여 차별과 인권침해가 이루어져서는 안된다는 것 때문이다. 
무엇보다 성평등을 위한 지원전략은 국제사회가 취하고 있는 보편적인 원칙과 지원전략을 최대한 존중하며, 해당 목표를 포괄적으로 실현하기 위한 협력적 지원태도를 갖는 것이 중요하다.

교육분야에서의 개발협력지원방안 또한 마찬가지이다. 단지 수단으로 인식되는 도구로서 교육을 이야기하는 것이 아니라면, 교육은 모든 인간의 인간다운 삶을 누릴 수 있도록 하기 위한 목적으 로 기능해야 한다. 따라서 누군가의 지식과 시스템이 이식되거나 전수되는 것이 아닌, 자기 삶의 맥락을 이해하고 세계관을 확대해나가도록 하는 목표이자 수단이 된다. 이러한 차원에서 BLG를 구성하는 하나의 영역을 넘어서서 교육분야, 특히 개발도상국의 여아와 여성 청소년을 대상으로 한 구상을 교육의 관점에서 다시 한 번 검토하고, 교육분야에 있어 보다 바람직한 BLG 사업방안 을 위한 논점을 제안하는 것이 필요하다. 따라서 본 연구는 $\mathrm{BLG}$ 를 교육의 관점에서 어떻게 접근 하는 것이 좋은지에 관한 논의를 제안하는데 가장 우선적인 목표를 두고 있으며, 이를 위하여 개 발협력에 있어 교육의 개념을 제시하고, 보다 인간중심적인 개발을 위한 교육 실현을 위한 논의 를 파키스탄의 중앙아시아협회(Central Asia Institute) 사례를 통하여 제시하고자 한다.

본고는 엄밀한 학술적인 논의를 위하여 준비했다고 하기 어렵다. 오히려 실천적 영역에서 방안 을 탐색하기 위한 정책적 방향과 제언을 담고 있는 것으로, 한국 정부의 의제인 BLG의 관점을 재검토하기 위한 과정으로 이루어졌다. 따라서 본고의 논의를 통하여 한국의 국제개발협력에서 여성과 교육을 연계하는 다양한 쟁점들을 확인하고, 보다 효과적인 BLG가 될 수 있기를 기대해 본다. 만약 본 논의가 보다 학술적인 장에서 토론될 수 있는 주제로 기능하려면, 개발도상국의 교 육, 특히 사회, 문화, 정치적으로 취약한 대상으로 자리잡고 있는 여아·여성청소년들의 삶과 그 들의 선택에 대해 보다 체계적인 이해가 선행되어야 한다. KOICA 뿐만 아니라 한국의 개발협력 전문가들이 구체적인 사업을 개발하고 실천하기 이전에 이들을 이해하기 위해 가까이하고, 또한 보다 포괄적으로 이해할 수 있도록 연구지원이 이루어질 수 있기를 기대한다.

이러한 연구목적에 따라, 본고는 다음과 같은 내용으로 구성된다. 우선 SDGs과 교육개발협력 의제에 대해서 검토한다. $\mathrm{EFA}$ 를 중심으로 논의되어 왔던 교육개발협력의제가 $\mathrm{SDGs}$ 를 통하여 다 른 개발목표의 하나이자 중요한 범분야 목표로 제시되어 있는 만큼 2015년 이후의 교육개발협력 의제가 갖는 의미를 검토해보는 것이 필요하다. 둘째, $\mathrm{BLG}$ 구상의 교육적 해석을 제시한다. 교육 과 보건을 두 축으로 하는 BLG의 내용에 대해서 개발도상국의 교육이슈 중에서 성평등 목표와 이를 통한 개발 전체의 전략방안은 어떤 것들이 있는지 제시할 것이다. 셋째, 개발도상국에서 여 아 및 여성 청소년들이 처한 교육적 상황은 어떠하며, 이를 해결하기 위한 효과적 노력들은 어떠 한 사례가 있는지 살펴볼 것이다. 이를 통하여 BLG 구상의 추진 방향 및 과제에 대해서 중요한 원칙들을 제시하고자 한다. 


\section{II. 지속발전목표와 교육개발}

국제개발협력분야에서 2015년은 특별한 해였다. 2000년 새천년개발목표(Millenium Development Goals, 이하 MDGs)가 등장한 이후 15 년 동안 국제사회의 빈곤퇴치와 발전을 위한 공동의 노력 이 있었고, 다음 15 년 동안의 공동행동 방안을 합의하였기 때문이었다. 지속발전목표(Sustainable Development Goals, 이하 SDGs)로 명명된 17개의 공동개발의제를 통하여 한국을 비롯한 국제 사회는 MDGs를 이어 인간 삶의 질을 개선하고 발전시키기 위하여 노력할 것이다. SDGs는 특정 한 영역의 개발목표만을 담고 있기보다는 보다 포괄적이고 영역을 아우르는 의제들을 목표로 설 정하였고, 이를 위한 논의의 장을 이어오고 있다.

교육은 인간의 기본적인 권리('인권)라고 선언한 1948년의 세계인권선언 이후 교육은 아동, 학 령기청소년, 그리고 성인들을 포함한 전생애에 걸친 중요한 삶의 목표이자 수단으로 기능해왔다. $\mathrm{UN}$ 의 교육, 문화, 과학기구인 $\mathrm{UNESCO}$ 는 $\mathrm{UN}$ 아동기금( $\mathrm{UNICEF})$ 을 중심으로 '모든 이를 위한 교육'(Education for All, 이하 EFA)을 하나의 커다란 개발의제로 내세워 교육의 중요성과 실천 을 이어왔다.

〈표 1〉EFA와 MDGs의 교육의제 비교

\begin{tabular}{c|l|c}
\hline & \multicolumn{1}{|c|}{ 모든 이를 위한 교육(EFA) } & \multicolumn{1}{c}{ 새천년개발목표 (MDGs) } \\
\hline \multirow{5}{*}{ 목표 } & 1. 양질의 유아교육기회 부여 & 목표2. 보편적 초등교육달성 \\
& 2. 양질의 무상의무초등교육제공 & (1) 초등교육 등록 및 졸업률제고 \\
& 3. 청소년 및 성인들의 학습 및 생활 기술교육충족 & 목표3. 성평등 수준 개선 \\
& 4. 15세 이상 성인비문해율 개선 & (1) 초중등교육에서의 섳차별일소 \\
& 5. 초중등학교교육에서의 성평등달성 & (2) 직업선택에서의 성평등수준개선 \\
& 6. 모든 교육분야의 질적 수준 혁신 & (3) 정치참여에서의 성평등수준개선 \\
\hline 모니터링주체 & \multicolumn{1}{c}{ UNESCO } & UNDP \\
\hline
\end{tabular}

출처: “EFA와 Post 2015 글로벌 교육의제: WEF의 성과와 한계, 그리고 과제", 유성상 (2015), 한국평생교육학회 2105년 도 연차학술대회(10월 18일, 제주대학교)의 심포지움 발표자료, pp. 10-11.

그런데 새롭게 SDGs에 포함된 개발의 영역들과 마찬가지로, 교육분야에서 2015년 이후 국제 사회의 개발목표를 인식하고 논의하는 것은 상당히 새로운 측면이 있다. 이전에 교육분야 개발협 력의제는 $\mathrm{EFA}$ 를 중심으로 제시했던 목표를 실천하는 과정이었고, 무엇보다도 $\mathrm{EFA}$ 가 교육분야 실천행동강령의 우선적인 토대였다. 그러나 향후에는 $\mathrm{EFA}$ 가 SDGs의 세부 타겟들과 통합되면서 교육개발의제는 교육만의 이슈를 떠나 보다 포괄적인 국제사회 개발의제의 부분이자, 곧 각 개발 영역간의 실천과 성과를 연계하는 중요한 기능을 부여받게 되었다. 
〈표 2〉 UNESCO와 UN의 Post 2015 교육의제 비교

\begin{tabular}{|c|c|c|}
\hline & 무스캇 협정 & 지속가능개발목표(SDGs) \\
\hline 발표일 & 2014년 12-14일 & 2015년 8월 2일 \\
\hline 발표주체 & UNESCO & UN \\
\hline 전체목표 & \multicolumn{2}{|c|}{ "Ensure equitable and inclusive quality education and lifelong learning for all by 2030" } \\
\hline 타겟 & 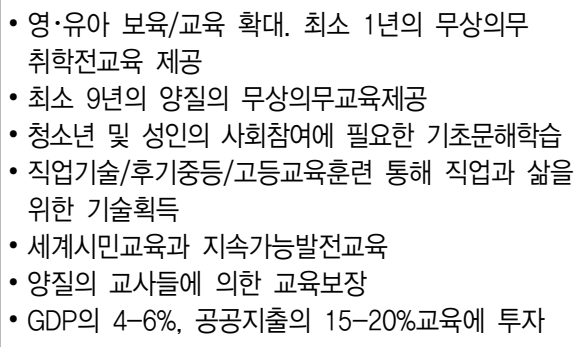 & $\begin{array}{l}\text { - 양질의 무상초중등교육 제공 } \\
\text { - 양질의 영유아 보육/교육접근 } \\
\text { - 대학을 포함한 양질의 직업기술교육훈련 접근 } \\
\text { - 고용 및 창업에 적절한 수준의 기술습득 } \\
\text { - 교육 및 기술교육훈련에 있어 성별 및 } \\
\text { 취약계층에게 평등한 기회 제공 } \\
\text { - 청소년 및 성인에게 기초문해제공 } \\
\text { - 지속가능발전 및 세계시민성 향상을 위한 지식과 } \\
\text { 기술 학습 }\end{array}$ \\
\hline 모니터링주체 & UNESCO & UNDP \\
\hline
\end{tabular}

출처: "EFA와 Post 2015 글로벌 교육의제: WEF의 성과와 한계, 그리고 과제", 유성상 (2015), 한국평생교육학회 2105년 도 연차학술대회(10월 18일, 제주대학교)의 심포지움 발표자료, p. 13.

이상의 교육개발목표에서는 모든 단계에서 양질의 교육을 성별, 인종별, 장애유무별, 사회경제 적 계층의 차이에 상관없이 평등하게 제공하고, 그러한 기회를 마련해 주어야 한다고 선언하고 있다. 여아와 여성 청소년, 심지어 성인 여성의 경우에도 이러한 공평한 기회를 얻는 대상에서 제 외될 수 없다. 그러나 전지구적으로 각 사회가 처한 사회, 문화, 정치, 경제적 여건은 이를 실현 하는데 적잖은 한계가 존재하고 있다는 점을 분명히 하고 있다. 아래 그림은 BLG 구상을 소개하 고 있는 $\mathrm{KOICA}$ 의 자료에 등장하는 것으로, 여아들이 구조적으로 학교교육의 기회를 적게 받고 있으며, 이러한 구조적 차별은 다양한 요인(성폭력, 조혼, 가사노동 등)에 의해 끊임없이 권력과 재화의 불균등한 분배로 재생산되고 있음을 보여주고 있다.

〈그림 1〉개발도상국 여아 교육환경

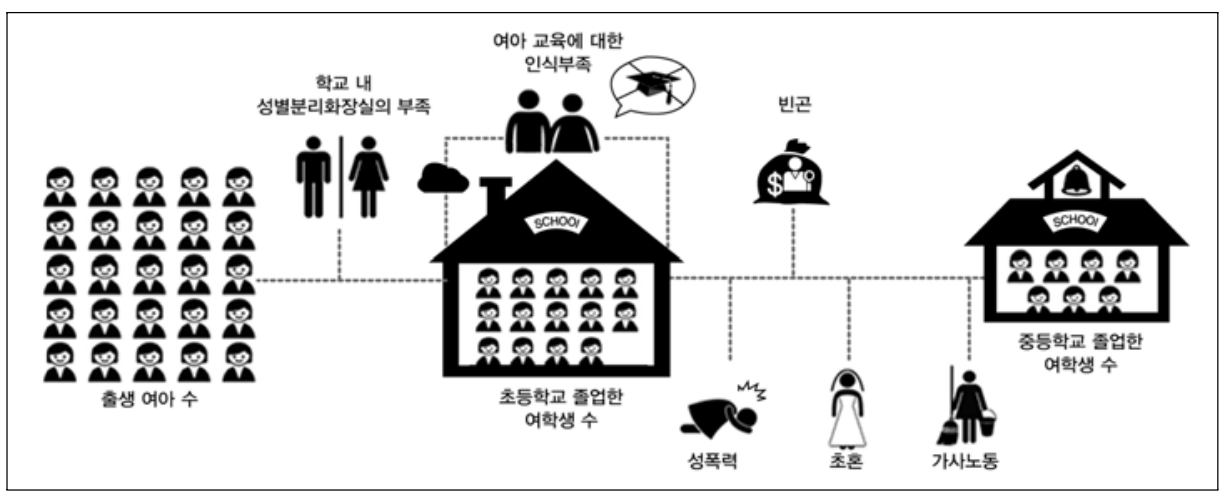

출처: “소녀들의 보다 나은 삶 구상” KOICA 뉴스레터 (2016년 1월), http://webzine.koica.go.kr/201601/content.php?code=201601_010315 (2016년 3월 5일 접속) 


\section{BLG 구상 내용과 의미}

\section{BLG 제안 배경 및 의미}

한국 정부는 2015년 9월에 열린 UN 개발정상회의에서 다음과 같은 제안을 국제사회에 제시하 였다.

"한국은 가장 취약한 상황에 처해있는 개도국 소녀들을 위해 보건·교육 무상원조 사업으로 '소녀들의 보다 나은 삶' 구상을 내년에 공식 출범시키고, 향후 5 년간 2 억 불을 지원할 계획 입니다. 소녀를 포함한 미래세대에게 보건과 교육 서비스를 제공하는 일은 지속가능한 미래 를 보장하는 가장 확실한 투자가 될 것입니다.”

$\mathrm{SDGs}$ 의 목표가 다양한 사회문화적 영역의 개발과제들을 포함하고 있다는 점에서 제시된 목표 를 실현하기 위한 개발재원을 확보하고, 이를 효과적으로 활용하는 것에 관심이 집중되어 왔다. 같은 자리에서 중국이 향후 15 년동안 120 억불을 제안하였고, SDSN(Sustainable Development Solution Network)은 개발재원에 관한 전세계적 논의를 주도하고 있는 것과 같은 맥락이다. 2009년 OECD DAC에 회원으로 가입한 이후 국제사회의 정치경제적 지형에서 개발선진국의 면 모를 갖추기 위한 한국정부의 개발협력 확대는 기대되었던 만큼 실현되지는 않았다. 전세계적 금 융위기와 경제위축을 주요한 요인으로 지목되기는 하지만, 선진국을 비롯한 국제사회의 개발협력 에 대한 효과성에 의심, 치열해지는 경쟁, 민영화로 대표되는 신자유주의적 이데올로기의 팽배는 국가를 대상으로 한 발전목표를 실현하는데에 소극적인 태도를 보일 수밖에 없었다. 한국의 경우 2000년 이후 15 년 동안 추진되어 온 MDGs에 주요한 행위자로 참여했다기보다는, 국제개발협력 의 후발주자로 국제사회의 개발을 둘러싼 이슈와 흐름을 읽어내고 동시에 참여해야 하는 과제가 있었던만큼 적잖은 시행착오를 겪어 왔다. 더욱이 한국인 사무총장이 $\mathrm{UN}$ 의 수장으로 자리잡으면 서, 국제개발협력을 큰 틀에서 관장하고 있는 UN에 보다 적극적으로 협력하고 지원하는 체제가 요구되었다. 지원규모가 적절한가 그렇지 않은가를 따지는 것을 차지하고라도, BLG는 한국이 국 가적 이해관계를 떠나서 권리에 기반한 국제사회의 개발협력이슈를 적극 포용하고 이를 실현해나 겠다는 의지로 해석하기 충분한 내용으로 볼 수 있다.

사실 BLG는 한국정부가 보건 및 교육분야에 있어 거의 처음이라고 해도 될만큼 의미심장하게 제시한 국제개발 구상이다. 2000년대 중반 참여정부에서 대아프리카 개발협력을 정책적으로 제시 한 적은 있지만, 실제 특정 분야의 개발협력 프로그램을 내세워 국제사회의 개발협력의제를 실현 하겠다고 나선 것은 드물었다. 이런 상황에서 $\mathrm{BLG}$ 는 가장 보편적으로 취약한 계층으로 인식되는 
개발도상국의 여아와 여성 청소년들을 대상으로 교육과 보건의료 지원을 하겠다는 것인 만큼 기 존 개발협력 프로그램의 방향과 내용을 보다 풍부하게 할 것으로 기대된다.

$\mathrm{BLG}$ 는 두 가지 영역에 관한 프로그램으로 인식되고 있다. 보건과 교육. 보건에 관한 논의는 본고의 전문성과 거리가 먼 것이므로 제외하고 교육분야 논의로 한정하여 제시하고자 한다. 무엇 보다 BLG는 개발도상국 여아 및 여성 청소년들의 교육권을 보장하는 것으로 요약할 수 있다. $\mathrm{BLG}$ 의 교육권 보장 프로그램은 보편적인 양질의 교육을 제공함으로써 개도국 아동들의 학업성취 도를 높이고 여성, 장애, 학교 밖 아동, 빈곤계층 및 분쟁지역 아동 등 소외된 계층에 대한 교육 접근성을 강화하기 위한 것이다. 이처럼 모든 아동에게 양질의 교육을 제공하는 것, 그리고 그 교 육의 혜택을 최대한 많은 아동들이 누릴 수 있도록 지원하는 것이 BLG 교육권 강화의 핵심 목표 이다. 교육권 향상을 통한 BLG 프로그램에는 (1) 교육의 기회 확대, (2) 교육의 질 향상, (3) 포용 적 교육을 보다 구체적인 내용으로 포함하고 있다. ${ }^{1)}$

제 I 장

개

\section{2. 교육적 개발을 위한 BLG 구상의 의미}

교육은 개발협력의 하위 영역(sector)으로 인식되어 왔다. 보건, 경제, 공공행정, 농업개발, 산 업 등과 마찬가지로 교육은 개발협력의 목표를 차지하는 축으로 기능하고 있다. 교육은 다시 하 위영역에 학교급별(영유아, 초등, 중등, 고등, 성인교육, 교육행정) 구분에 따른 프로그램과 내용 별(인프라, 기자재, 역량강화 등) 지원을 포함하고 있다.

그러나 교육은 개발협력의 한 영역이자 각 분야를 아우르는 연계체제로 작동하고 있으며, 뿐만 아니라 각 분야 개발목표들을 실현하게 하기 위한 기본적인 토대로 인식되어야 한다. 교육이 여 러 영역의 한 목표를 지칭하는 개념을 넘어서서 다른 개발 목표들을 실현하기 위한 중요한 기본 플랫폼이자 개별 목표들을 아우르게 하는 접합제가 되는 것이다. 개발의 개념과 국제개발의 궁극 적인 목표를 두고 다양한 의견이 공존하고 있고, 구체적인 숫자로 제시되는 경제성장을 넘어선 개발협력을 추구하자는 대안적인 개발담론이 설득력을 얻는 것은 개발들과 또 다른 '개발들' 사이 에 존재하는 교육의 기능과 역할을 제대로 인식하지 못하고 있기때문에 발생한다. 어쩌면 이번 SDGs의 교육의제에서 지속가능발전교육(Education for Sustainable Development, ESD)과 세 계시민교육(Global Citizenship Education, GCED)을 포함한 것은 이러한 개발들 속의 교육에 대한 보다 진전된 인식을 요구하는 것이라 이해할 수 있다.

교육을 '정해진 지식체계를 효율적인 방식으로 잘 전달하는 것'으로 이해하고 있다면 교육이 가

1) “ODA 연구보고서-소녀들의 보다 나은 삶” KOICA 블로그http://m.blog.naver.com/prkoica/220645155234

(접속일 2016년 3월 4일) 
진 복잡하고 다층적인 속성을 제대로 이해한다고 볼 수 없다. 교육은 개인과 사회적인 차원에서 서로 다른 기능을 담당하고 있다. 또한 개인과 사회적인 차원에서도 서로 상반된 기대 속에서 역 동적인 역할을 수행하고 있다. 거시적으로는 특정한 사회의 질서와 체계를 유지하도록 기능하는 가 하면, 새로운 체계가 등장하고 성장하며 자랄 수 있도록 끓임없는 변화와 혁신의 토대가 되기 도 한다. 이 두가지 상반된 기능과 역할이 어떻게 특정한 사회에서 적절한 조화를 이루며 사회변 화의 방향을 만들어가는지는 도무지 알 수 없다. 단지 기대되는 미래의 모습을 그리고 이를 위해 노력할 뿐이다. 개인차원에서는 좀 더 사회심리적인 방식으로 교육은 기능한다. 심리학적 측면에 서 교육은 개인이 지식을 습득하고, 이에 바탕하여 자신의 삶의 문제를 해결하도록 기능한다. 따 라서 개인 외부의 어떤 지식체계를 받아들이고, 또 얼마나 어떻게 받아들이는가가 중요한 요소가 된다. 그러나 개인이 처한 사회의 자연, 문화, 정치, 경제적 맥락의 복잡성을 떠올린다면 사회 속 의 한 개인이 접하고 습득하는 지식이라는 것의 문제부터 시작해서, 체득된 지식체계가 어떻게 활용되는지에 관해 기능하는 교육이라는 활동이 결코 단순하게 작동하는 것이 아니라는 점을 알 게 된다. 즉, 개인은 자신을 둘러싼 사회문화 속에서 자신의 생존과 번영에 필요한 지식을 습득하 는 과정이지만, 지식 자체가 억압적인 요소가 아니라 보다 변혁적인 요소로 작동할 수 있도록 스 스로를 끊임없이 개입해나가도록 한다. 교육은 이를 작동하게 하는 시작점이자 곧 그 결과이기도 하다. 즉, 교육은 개인이 사회에서 자신의 삶의 문제를 스스로 해결할 수 있도록 자유로운 선택의 가능성을 확대해나가고, 실제 이를 실행해나가도록 해내는 총체적 능력을 만들어낸다. 교육을 '개 인과 사회가 자유롭게 선택할 수 있는 가능성을 보다 확대하는 과정이자 곧 결과'로 이해한다면, 단지 한 국가 속의 시스템으로서 학교교육의 기회를 부여하는 것, 이를 위한 국가적, 시민사회적 재정지원 정도로 교육을 이해하는 것이 얼마나 편협한 교육적 실천에 국한된 것인지 이해할 수 있을 것이다.

이러한 측면에 있어 개발도상국 여아와 여성 청소년들의 교육권을 강화하기 위한 BLG 구상은 단지 이들에게 학교교육의 기회를 제공하자는 재정지원 프로젝트가 되어서는 안 된다. BLG는 한 사회에서 여성이 사회문화적 편견과 차별로부터 자유롭게 스스로의 삶을 개척할 수 있도록 선택 과 기회의 자유를 넓힐 수 있는 수단이 되어야 한다. BLG에서 제시하고 있는 개발도상국 여아와 여성 청소년들의 교육권 강화를 위한 구체적인 내용에 세 가지, 교육의 기회 확대, 양질의 교육제 공, 그리고 포괄적 교육 실천이 포함된 이유가 여기에 있다고 본다. 그러나 아직까지 BLG를 어 떻게 실현할 것인지에 대한 구체적인 프로그램과 중장기적인 성과 청사진이 제시되지 않은 상황 에서 이 세 가지의 큰 주제만으로 BLG가 특별한 구상이 될 수 있을 것이라 판단하기 어렵다. 그 러나 (보건을 포함하기는 하지만) 교육권 강화를 통하여 개발도상국 여아들의 삶의 질을 높이겠다 는 방안이 SDGs에 임하는 한국의 개발협력 행동으로 제시되었다는 점에서, BLG 구상이 한국의 
국제개발협력에 있어 가지는 의미를 다음 네 가지로 제시하고자 한다.

첫째, 국제개발협력에서 양적 차원의 지원을 넘어 질적 차원의 지원과 협력을 고려한 구상이라 고 할 수 있다. 특히 교육분야의 경우에는 더욱 이에 대한 변화가 강조될 수 있다. 한국의 개발협 력재원에 있어 교육 지원이 차지하는 비중은 작지 않다. (〈표 3〉 참조)

\begin{tabular}{c|c|c|c|c}
\hline 구 분 & 2006년 & 2007년 & 2008년 & 2009년 \\
\hline 호주 & $278.2(18 \%)$ & $359.2(25 \%)$ & $498.5(16 \%)$ & - \\
\hline 독일 & $1,367.1(24 \%)$ & $1,463.8(24 \%)$ & $1,732.3(21 \%)$ & $1,808.9(21.8 \%)$ \\
\hline 일본 & $889.3(11 \%)$ & $719.7(8 \%)$ & $787.7(6 \%)$ & - \\
\hline 미국 & $476.9(3 \%)$ & $841.4(5 \%)$ & $1,094.4(5 \%)$ & - \\
\hline 한국 & $135.2(22 \%)$ & $160.9(16 \%)$ & $114.3(8 \%)$ & - \\
\hline 세계은행 & $773.8(10 \%)$ & $1,803.9(14 \%)$ & $1,324.9(12 \%)$ & $2,038.1(14.3 \%)$ \\
\hline UNICEF & $53.1(10 \%)$ & $63.0(8.9 \%)$ & $73.8(10.4 \%)$ & $65.7(8.76 \%)$ \\
\hline
\end{tabular}

출처: DAC/OECD (2011) 자료 참조. (KOICA 교육분야 전략(2011-2015), p. 7 재인용)

그러나 교육분야의 사업은 장학금, 해외봉사활동, 그리고 인프라 및 기자재 지원이 거의 대부 분을 차지해 왔다. 교육에 대해서 갖는 인식이 추상적이고 중장기적인 비전에 근거한다는 점, 그 리고 교육을 둘러싼 이념적 대립과 교육지원의 성과에 대한 논쟁이 끊이지 않는다는 점을 고려해 본다면, 한국의 교육분야 지원 사업들은 내용적으로 거의 변함없이 가시적인 숫자를 생산해내기 위한 양적 성과를 쌓는데 집중해왔다. 그러나 BLG는 개발도상국의 여아들을 대상으로 이와 유사 한 방식의 양적 성과를 내겠다고 하겠지만, 정작 특정한 사회, 문화, 정치적인 차별과 편견의 대 상인 여아/여성 청소년들을 대상으로 지금과 동일한 수준의 프로그램으로 접근하는 것에 만족할 수 없을 것이다. 따라서 차별과 편견, 그리고 억압의 사회, 문화, 정치적 맥락들을 이해하고, 이 를 극복하기 위한 지원과 협력의 질적 측면이 고려되어야 한다. 만약 5년 이후 BLG의 성과를 위 하여 몇 개 국가에 몇 명의 대상자들에게 얼마의 재원을 쏟아부었다는 것으로 평가 보고서가 마 무리되리라 기대하지 않는다. 적어도 여아들이 어떤 방식으로 자신의 삶을 스스로 개척할 수 있 도록 구체적인 교육적 개입이 이루어졌고, 이들의 삶이 어떻게 바뀌었는지 기술될 수 있어야 할 것이다.

둘째, 한국의 개발협력에서 교육의 의미를 새삼 강조할 수 있는 계기가 될 것이다. 앞서 교육 의 의미를 일반적인 개념에서부터 국제사회의 개발협력의 맥락에까지 어떻게 인식할 수 있는지 제시하였다. 개발협력에 있어 교육의 의미를 새삼스럽게 해석해 내놓는다고 당장 교육적 개발협 력이 이루어질리 만무하다. 문제는 개발협력이 궁극적인 목표를 실현하기 위한 가장 효과적인 방 
법과 전략이 무엇인지에 대한 논의가 필요하지만, 이에 대한 논의의 장 또한 잘 이루어지지 않는 다. 여전히 개발협력의 분야 중 하나로 인식되는 교육에 대한 개념을 보다 확산하려는 계기가 필 요한 상황에서 $\mathrm{BLG}$ 는 중요한 계기로 작동할 것이다. 사회문화(정치)적 구조에 의해 숙명처럼 주 어지는 여아들의 삶을 바꿀 수 있는 것은 교육 이외에는 생각할 수 없기 때문이다. 이들에게 어 느 시기까지의 교육을 보장하고, 제도화된 학교교육의 기회를 위하여 어느 정도까지의 내용을 지 원해야 하는가는 부차적인 문제이다. 이들에게 자기 삶의 디자인이 중요하다는 가능성을 확인하 도록 해 주는 것, 이것이 교육을 통해서만 가능하다는 것을 한국 개발협력 공동체에 메시지로 던 질 수 있다는 점이 중요하다. BLG는 이를 위한 공론의 장을 만들고, 구체적인 프로그램의 효과 성을 두고 다양한 영역의 전문가들에게 교육의 의미에 대해 고민해 보게 하는 매개 역할을 할 것 이다.

셋째, BLG 구상은 과정 자체를 성과의 하나로 여기도록 하고, 기존 사회의 변화를 일구는 여 성들의 삶 속에서 개발협력의 성과를 찾아내도록 할 것이다. BLG 구상에 향후 5 년동안 2 억불이 라는 적지 않은 재원이 투입되는만큼 성과에 대한 논쟁이 적지 않으리라 생각된다. $\mathrm{DAC} / \mathrm{OECD}$ 에서 개발원조 효과성 논쟁을 이끈 일련의 국제회의 (파리(2005), 아크라(2008), 부산(2011) 등) 에서 개발협력의 성과는 결코 경시될 수 없는 영역이다. 앞서 이야기한 것처럼, BLG에 투입되는 재원의 총액에 따른 사업 책무성은 명료하게 제시되어야 한다. 그러나 사업 책무성을 넘어서서 $\mathrm{BLG}$ 구상이 담고 있는 국제사회의 개발협력 과제는 특정 지역사회/공동체/사회/국가의 평균적인 경제성장을 의미하는 것을 넘어서는 것이어야 한다. 이는 단지 몇 명이 학교교육을 받았고, 직업 기술교육에서 특정 프로그램을 이수하였다는 보고에 그쳐서는 안 된다는 것을 의미한다. 또한 한 공동체에서의 여아대상 프로그램이 다른 사회문화적 공동체에서 똑같이 되풀이될 수 있는 것이 아니라는 점에서 결코 일반적인 성과와 효과를 제시할 수도 없다. BLG는 지난 MDGs 추진 기간 동안 제기되었던 평균적 경제성장에 기반한 성과지표의 한계를 분명히 짚어내고, 이를 극복할 수 있는 인간발전(human development), 인권중심의 지역사회 발전을 성과로 내세울 수 있는 계기 가 될 수 있을 것이다. 아직까지 구체적인 SDGs의 17 개 개발목표를 위한 성과지표가 성안되지는 않았지만, 적어도 $\mathrm{SDGs}$ 에서의 성과지표는 MDGs에서 내세웠던 일률적인 지표를 넘어서 사회문 화적인 변혁의 과정을 지표로 껴안을 것으로 기대된다. BLG 구상은 한국의 국제개발협력의 성과 를 어떻게 정할지에 대해 논의를 전개하게 할 것이다. 구체적인 개발협력의 성과를 실현해나가기 위한 과정이 효율성보다는 효과성에 터하도록 한다는 점, 그리고 단기적 성과에 집중하기 보다는 중장기적인 변혁을 염두에 둔 장기간의 지원협력을 고려하게 될 것이다.

넷째, BLG 구상은 한국의 국제개발협력에 있어 인권, 불평등, 차별, 편견, 글로벌 정의 등의 주제를 보다 자주, 그리고 심각하게 고려하게 할 것이다. 과거 제국주의 시대 식민지를 거느린 국 
가들에서부터 시작된 '국가간 원조'는 근대적 이분법으로서 개발과 저개발의 구분을 넘어서 새로 운 개발의 관점을 탐색해 왔다. 개발선진국의 근대적 발전모델을 따르는 것이 국제개발협력의 유 일한 관점이었던 시대를 넘어서서 근대 이후의 탈이데올로기적이고, 탈식민적이며, 탈구조적이며, 보다 다양한 개발의 관점들이 긴장과 갈등의 지형을 만들고 있다. 또한 이를 통하여 보다 이상적 인 국제사회의 개발 지향(orientation)이 만들어지고 있다. 작금의 비판적 개발이론들은 인권기반 (human-rights based)의 개발을 통하여 개개인의 삶의 질을 향상하는 것을 내세우고 있고, 이 는 일반적인 통념으로 받아들여져 있다. 그러나 개인의 선택과 사회, 국가의 개발에 대한 관점이 전 지구적인 이념, 권력, 자본에 의해 영항을 받으면서 인권, 차별극복, 공정/평등, 그리고 글로 벌 사회정의라는 국제개발협력의 대의들(causes)은 공허한 수사적 표현에 머물러 있는 경우가 허 다하다. BLG 구상은 적어도 이러한 표현들이 구체적인 프로그램으로 만들어지는 과정에 어떻게 반영될 것인지, 이를 위한 한국과 특정 국가, 특정 공동체, 특정 개인의 관계가 어떻게 형성되어 야 하는지에 대해 민감하게 작용해야 할 것이다. 따라서 BLG 구상을 통한 다양한 논의의 장들은 한국의 국제개발협력에 보다 정당한 개발협력의 수사들을 동원하고, 이를 실현할 수 있도록 추동 할 것이다.

\section{IV. 개발도상국 여아 교육을 위한 중앙아시아협회(CAI)의 사례와 사업의 원칙}

중앙아시아협회(Central Asia Institute, 이하 CAI)는 그렉 모르텐슨(Greg Mortenson)과 그 를 후원하는 사람들에 의해 설립되었다. 우연한 기회에 맺게 된 인연과 약속으로 아프가니스탄과 파키스탄 국경지대인 히말라야 산지에 여아들을 위한 학교를 짓는 사업을 시작했고, 지금까지 이 들을 위한 학교 신설 및 교육기회 확대를 통한 교육권 강화 사업을 진행하고 있다. CAI는 그렉 모르텐슨이라는 인물을 빼고 이야기할 수 없지만, 본 논의이 핵심인 BLG 구상과 대상이 되는 개 발도상국의 여아들의 교육적 상황을 고려할 때 특정한 개인을 중심에 두고 논의를 전개하기 어렵 다. 따라서 본 장에서는 특정한 개인을 거명하기보다는 $\mathrm{CAI}$ 를 내세우고, CAI가 활동하게 되는 파키스탄 북부 지역, 특히 탈레반 점령지역에서의 활동에 대해서 다루고자 한다. 이를 위하여 이 슬람을 국교로 삼고 있는 파키스탄의 사회문화적, 교육적 상황에 대해 간략하게 기술할 것이다. 또한 CAI 사업의 내용보다는 CAI가 이곳의 여아들을 위하여 진행한 활동의 기본 원칙들을 간략 하게 소개할 것이다. 이를 토대로 BLG 구상의 향후 추진방향에 대해서 정책제언을 제시하고자 한다. 


\section{1. 파키스탄의 사회문화적 맥락}

파키스탄은 중앙아시아와 중동의 경계부분에 있으며 남아시아에 속해 있다. 파키스탄 동쪽에는 인도, 북동쪽에는 중국, 서쪽에는 아프가니스탄과 이란이 위치해 있다. 수도는 이슬라마바드이며 주요 도시로는 카라치, 라호르, 라왈핀디 등이 있다. 파키스탄의 북쪽과 서쪽은 산악지대로 되어 있는데, 카슈미르 지역에는 세계에서 두 번째로 높은 $\mathrm{K} 2$ 등 세계에서도 높은 봉우리들이 많아 산 악인들의 발길이 잦다. 서부 중앙의 발루치스탄 지역은 높은 사막 고원지대로 되어 있고, 중앙의 펀자브 지역은 인더스 강이 지나 비옥한 평화지대를 이룬다. 파키스탄은 전 세계에서 브라질에 이어 6 번째로 인구가 많은 나라이며, 펀자브인, 파슈툰족, 신드족 등 다양한 민족으로 구성되어 있다. 인도네시아에 이어 2 번째로 큰 이슬람 국가로서 국민의 대부분이 이슬람교를 믿으며, $75 \%$ 의 수니파, $20 \%$ 의 시아파 외에도 다양한 이슬람 종파가 존재한다.

이슬람은 '국가와 종교'를 분리하지 않는다. 이슬람 세계에서 현 상황은 모든 사람들이 정치, 경제, 사회, 종교를 함께 보는 제도에 속해 있다. 이들에게 종교는 삶과 정치제도의 완전한 법전 이다. 그것은 모든 것이다.라고 언급했다. 이런 유대감은 파키스탄도 마찬가지이며, 그만큼 이슬 람교는 파키스탄 인들의 정신 및 일상생활 속에 뿌리깊게 자리잡고 있다. 2013년 미국 국무부 산 하의 종교자유위원회는 종교의 자유가 보장되지 않는 파키스탄을 현재 미국 정부에 의해 종교 자 유 침해 '특별 관심 국가'로 선정되어 있지 않은 국가 중 최악의 종교 탄압 국가로 규정했다. 또한 파키스탄은 핵무기 보유를 선언한 유일한 이슬람 국가로서 매우 잘 훈련된 군대 및 다량의 군사 무기를 보유하고 있어 세계 8 위의 국방력, 세계 12 위 군사력을 지닌다. 파키스탄은 이슬람협의기 구, 남아시아지역협력연합, 8 개 개발도상국, G20 개발도상국, 경제 협력기구의 창립국이다. 또한 $\mathrm{UN}$, 영국연방국, 국제무역기구, 상하이 협력기구, G33 개발도상국, 77 개발도상국 연합, 미국의 주요 비나토 동맹국(major non-NATO ally)이기도 하다.

그러나 파키스탄의 2014년 현재 1인당 국내총생산(GDP)는 세계 139 위, 인간개발지수(HDI)는 세계 146위로 파키스탄의 사회 경제적 상황은 아직 매우 열악하다. 2007년에 수집되어 2013년 발표된 UNDP 자료에 따르면 파키스탄의 다차원적 빈곤 지수(MPI)는 남아시아 지역에서 방글라 데시 다음으로 최하위인 것으로 나타났다. 게다가, 비록 방글라데시의 다차원적 빈곤 인구 비율은 파키스탄보다 높았지만 박탈감의 정도는 파키스탄이 더 높았다. 또한 방글라데시와 네팔에서는 생활 수준 차원이 보건과 교육 차원보다 빈곤 지수에 영향을 주었으나, 파키스탄에서는 보건 차 원이 나머지 차원보다 더 큰 영향을 주는 것으로 나타났다.

당시 파키스탄의 거듭된 정치적 불안정과 군부독재, 정부 공백 속에서 이슬람 극단주의 집단인 탈레반2)은 한때 파키스탄을 장악하고 파키스탄을 극심한 무력 공포 상황으로 빠뜨렸다. 극단적인 
이슬람 이념을 강요하면서 파키스탄 국민들의 일상생활 모든 면에서 자유를 억압했다. 언론을 탄 압하고 대부분의 방송국을 폐쇄하여 파키스탄을 국제사회에서 철저히 고립시켰다. 또한 예방 접 종을 중단시키거나, 바미얀 불상을 파괴하고 춤과 음악을 금지하는 등 문화 예술을 탄압했다. 탈 레반 정권 하에서 천명이 넘는 평범한 주민, 경찰들이 살해당했다고 알려져 있다.

\section{2. 파키스탄의 교육과 여아교육의 실제}

파키스탄의 교육은 크게 5 단계로 나뉜다. 초등교육(1 5학년), 중등교육(6 8학년), 고등교육 (9 10학년), 중간과정(11 12학년), 그리고 졸업과 석박사 과정인 대학교육이 있다. 모든 대학교 육은 지자체의 책임이다. 연방정부는 대부분 학교의 인가, 교과과정 발전, 연구자금조달을 지원하 나, 정부의 교육 재정이 부족해 학교 수가 턱없이 부족하고 제대로 관리되지 못했다. 법적으로 초 등교육은 모두에게 무료이며 의무교육이나, 2009년 자료에 의하면 오직 5 세 이상 소년들 $70 \%$, 2.5 세 이상의 소년들 $60 \%$ 만이 교육을 받고 있었다. 당시 파키스탄 연방교육부의 통계를 보면 초 등교육 상태는 매우 불만족스럽다. 파키스탄의 문맹률은 $54 \%$ 이며 남성의 문맹률은 $37 \%$ 인데 비 해 여성은 $64 \%$ 로 그 차이가 컸다. 한국의 $18 \sim 23$ 세 학생들의 당시 고등교육률이 $68 \%$ 였던데 비 해 파키스탄의 18 23세 학생의 고등교육률은 고작 2.9\%에 불과했다. 1991년까지 파키스탄에는 오직 2개의 사립대학교만이 있었다.

이슬람교 고등교육기관인 마드라사는 사우디아라비아 등 석유재벌들이 포진한 이슬람 재단의 자본력을 바탕으로 한때 급속히 확산되었다. 마드라사는 현대의 필수과목이 아닌 이슬람 교리를 중심으로 한 이슬라미야트를 가르쳤다. 역사 교과서에서는 파키스탄이 1947년이 아닌 훨씬 이전 부터 존재해온 것처럼 하거나, 힌두교도와 유대인을 매도하는 등 역사를 왜곡했다. 고아나 가난한 학생들도 받아들이고 숙식을 제공했기 때문에 많은 불우한 파키스탄 청소년들이 마드라사로 흡수 되었다. 그러나 마드라사의 교사들은 글을 읽고 쓰지 못하는 자들이 많았고, 파키스탄이 전시체제 에 돌입하면서 극우 이슬람 교리를 세뇌시키고 군사훈련을 시켜 무자헤딘, 즉 이슬람 저항군을 키워 지하드에 참전하게 하는 등 많은 가난하고 불우한 청소년들을 전쟁으로 내몰아 목숨을 잃고 불구로 만드는 결과를 낳았다.

특히 탈레반은 여성들의 교육을 전면 금지시키고 모든 여성들을 집안의 특정지역(푸르다)에 감 금시켰다. 탈레반은 부르카(얼굴와 온몸을 가리는 검은 옷) 착용을 의무화한 것은 물론, 여성들의

2) 탈레반: 탈립(Talib)은 파슈툰어로 마을 학교에서 책을 읽는 학생을 의미한다. 탈레반은 이슬람의 기초 위에 아프가니스 탄을 재건립하고자 이슬람 원리주의자들에 의해 조직되었다. 무력으로 아프가니스탄의 주요 도시를 점령하고 1995년 권 력을 잡았으나, 2001년 연합국의 군사력에 의해 패퇴했다. 극단적인 이슬람 원리주의 통치로 국제사회의 비판을 받았으 나, 파키스탄, 사우디 아라비아, 아랍 에미레이트 등의 이슬람 국가에서는 정통성 있는 통치자로 인정받아왔다. 
사회활동을 전면 금지시키고 심지어 집 밖에 여성이 혼자서, 혹은 여성들끼리 외출하는 것도 막 았다. 남성이 특정 여성을 간통했다고 지목하기만 하면 여성을 유죄판결에 돌로 때려죽이게 하는 끔찍한 사형제도가 있었으며, 이를 막으려면 4명의 목격자를 데려와야만 했다. 여성이 다니는 학 교는 모두 폐쇄시키고, 교육활동을 중단하지 않을 경우 학교를 폭파하거나 관련 교육자들을 암살 했다.

\section{CAl와 교육사업}

그렉 모텐슨이 설립한 중앙아시아협회(CAI)가 주목을 받게 된 것은 잡지 〈퍼레이드〉의 헤드라 인 기사에 관련 소식이 실리면서부터 였다. 이 기사를 통해 미국의 50 개 전체 주와 미국을 제외 한 20 개국에서 1 만 8 천통이 넘는 편지와 이메일이 쏟아졌다. 그리고 폭탄과 무력이 아닌, 책과 교육을 통한 테러와의 전쟁이라는 새로운 접근법을 보여줬다. 이후 모텐슨이 저자로 참여한 〈세 잔의 차(Three Cups of Tea)〉와〈돌을 학교로(Stones into Schools)〉는 뉴욕 타임스 베스트셀 러로 여러 사람들에게 파키스탄 및 아프가니스탄의 열악한 교육 환경과 현장 교육 운동가들의 어 려움을 전세계에 알려 더 많은 관심과 후원을 이끌어냈다. 80여 곳의 새 학교를 짓고 정부 학교 를 증축하거나 지역 교육 환경을 개선해나갔으며, 이로써 3 만여 명이 넘는 아이들이 교육의 혜택 을 받을 수 있게 되었다. 현재는 중앙아시아협회(CAI) 공동창립자로서 파키스탄을 넘어 아프가니 스탄까지 학교 짓는 일에 계속 매진하고 있다.

모텐슨은 먼 타국의 지극히 평범한 개인이 뜨거운 인간애와 의지로 얼마나 큰 일을 해낼 수 있 는지 몸으로 보여줬다. 그의 노력을 통해 파키스탄 산간지역에 수많은 학교를 짓고 여성 교육을 장려하여, 모든 아동의 교육권을 보호하는데 일조했다. 또한 아동을 상대로 한 학교 교육뿐 아니 라 성인을 상대로 한 직업기술 등 교육 현장의 요구에 맞는 폭넓고 탄력적인 교육 운동을 함께 전개했다. 또한 그는 이슬람교 원리주의로 고통 받는 여성교육 실태를 국제사회에 알려 커다란 관심과 지지, 후원을 이끌어냈다.

\section{4. $\mathrm{CAl}$ 의 교육사업 원칙과 $\mathrm{BLG}$ 구상에의 함의}

CAI는 모텐슨의 책 두 권(〈세 잔의 차 (Three Cups of Tea)〉와 〈돌을 학교로 (Stones into Schools)〉)과 〈희망을 향한 여정 (Journey to Hope)〉이라는 부정기 간행물을 통하여 활동 을 전하고 있다. 기부금과 후원에 의존하고 있는 시민사회단체로 불투명한 재정 관리로 연방검찰 의 기소와 재판 등으로 신뢰도에 큰 흠을 안고 있는 것은 사실이지만, CAI에서는 모텐슨을 재신 
임하고 그의 참여, 즉 가장 열악한 곳의 여아들을 위한 교육권 강화를 위한 사업에 책임을 맡기 고 있다. 그는 1990 년대 중반 이후 20 여 년에 걸쳐 가장 열악한 자연지형에 살고 있는 사람들에 게 학교 교육의 의미를 전달하고, 무엇보다도 그 기회의 반 이상이 반드시 여아에게 돌아갈 수 있도록 노력했다는 점에서 다른 사업과 차별적인 특성을 보여주고 있다. 이하에서는 CAI가 이슬 람 지역의 여아들에게 교육기회를 확대하기 위해 추진한 사업의 기본적인 원칙들을 공유하고, 이 러한 원칙들이 향후 $\mathrm{BLG}$ 구상의 사업추진 방향에 어떠한 함의를 가지는지 논의하고자 한다.

\section{가. $\mathrm{CAl}$ 의 교육사업 원칙}

CAI가 히말라야 산지, 이슬람 원리주의적 문화 공동체를 이루고 있는 지역에서 여아들의 교육 기회 확대를 위해 어떠한 접근과 노력을 기울였는지, 구체적인 사업을 실행하기 위한 절차와 성 과를 어떻게 실현해나갔는지에 대해 다음 다섯 가지의 원칙을 만들었고, 또 지켜왔다.

첫째, 세 잔의 차 원칙. 이는 사회문화적 헤게모니를 주도하는 지역주민들의 이야기를 귀담아 듣고 이들과의 관계를 우호적으로 만든다는 원칙이다. 히말라야 산지의 사람들에게 있어 차(茶)를 함께 나눈다는 것은 관계를 형성한다는 것과 같은 말이다. 한 잔의 차를 함께 마실 수 있는 관계 는 주인과 손님의 관계로, 두 잔의 차를 함께 마실 수 있는 관계는 서로 친구의 관계로, 세 잔의 차를 함께 마실 수 있는 관계는 가족 공동체의 일원이 되었다는 관계를 의미한다. 그러나 여기에 는 함께 차를 마시면서 서로의 시시콜콜한 이야기를 주고 받으며, 긴 침묵을 견디면서 서로를 깊 이 이해할 수 있기 위한 시간이 전제되어야 한다. CAI는 지역주민들과의 꽤 오랜 만남과 이야기, 굳이 교육이 아니더라도 서로의 삶과 애환에 대한 교류, 그리고 지역 주민들의 삶에 녹아 드는 방식으로 그들의 필요와 요구를 이해하고 발견할 수 있었다.

둘째, 교육 이전의 우선 해결과제 원칙. 히말라야의 산지에 사는 사람들이라고 학교와 교육의 중요성을 전혀 모르면서 살지 않는다. 또한 이슬람 원리주의자들로 탈레반의 정치적 영향을 받고 있기는 하지만, 자녀들, 특히 여아들의 교육기회가 아이뿐 아니라 가정에 어떠한 변화를 가져다 줄 것인지에 대해서 적잖은 기대를 갖고 있다. 이미 전지구적 학교교육 제도는 이들의 삶에도 다 양한 미래적 비전을 심어놓았다. 그러나 CAI는 자신들이 하는 학교 짓기나 아이들을 충동하여 학 교를 다니도록 하는 일에 매달리기 전에 지역사회에 가장 우선적으로 해결해야 할 과제를 먼저 찾아 다녔다. 다리 건설문제, 물 문제, 공공보건문제(전염병 등), 지진 이후의 마을 재건문제 등은 $\mathrm{CAI}$ 가 학교를 짓자고 함께 이야기를 나누었던 지역사회의 주민들에게 있어 교육보다 먼저 해결 되어야 할 사안들이었다. 모든 문제들이 쉽게 해결되는 것도 아닌데다가 적잖은 재정지출이 요구 되는 사안이라면 당장 뛰어 들어 책임지고 해결하겠다고 할 수 있는 일도 아니었다. 그러나 적어 
도 지역주민 입장에서 왜 그 일이 중요하고 또 해결되어야 하는지, 코 앞에 닥친 문제를 함께 공 유하고 해결하기 위해 머리를 맞댄다는 것의 의미를 나누는 것은 그 어떤 새로운 일을 시작하는 것보다 필요한 것이었다. CAI는 교육과 학교라는 이름을 굳이 붙이지는 않았지만, 지역사회에서 가장 필요한 일을 자신들의 교육사업에 연계하여 추진하며, 교육을 성공적으로 실현할 수 있도록 하는 든든한 버팀목으로 삼았다. 특정한 지역사회의 우선 해결과제라는 것이 모두 명확하게 드러 나는 것은 아니다. 그러나 CAI는 적어도 짧지 않은 시간동안 지역주민들과 함께 시간을 보내고 생활하면서 이들의 삶이 지닌 전통과 가치, 그리고 덕을 발견하기 원했고, 이를 토대로 진솔한 지 역사회의 문제를 터놓고 이야기할 수 있는 신뢰관계를 쌓을 수 있었다.

셋째, 지역사회의 요구에 의한 사업의 시작, 지역주민에 의한 학교 운영 원칙. (문서에 따르면) $\mathrm{CAI}$ 는 철저하게 사업형성을 지역사회에 맡겨두었다. 그리고 현지 지부의 담당자들이 지역사회와 협의하여 학교건립을 위한 기획 및 추진이 이루어지도록 했다. 이때 CAI에서는 다음과 같은 조건 을 내걸었다.

(1) 학교 건물을 짓는 비용은 CAI에서 충당하지만, 학교대지 및 건축 노동은 지역사회에서 맡 는다.

(2) 등록학생의 $50 \%$ 이상을 반드시 여아로 받는다.

(3) 학교운영에 있어 초기 5년 동안의 교사봉급은 CAI에서 지급하지만 이후에는 국가 혹은 지 역에서 부담한다.

(4) 학교 운영에 있어 지역사회의 적극적인 참여를 시스템화하기 위하여 학교운영위원회를 두고 상설 운영한다.

사실 이러한 조건을 내걸고 학교를 짓자고 하기까지 지역사회와 종교를 중심으로 한 문화공동 체는 적잖은 회의를 거쳐야 한다. 가장 합의하기 어려운 주제는 바로 여아들을 등록 학생수의 $50 \%$ 이상으로 해야 한다는 조건이었다. 근본주의적 이슬람교도로서 그들은 여자는 학교교육을 받아서는 안될 뿐만 아니라, 세상에 대해서 무언가를 알려고 하는 것 자체를 금기시했다. 교리상 으로 보면 그들을 보호한다는 취지였겠지만, 꽤 오랜 시간이 지나면서 남성과 여성의 불공정한 권력관계를 유지하는 관례로 굳어져 온 무형의 사회적 구조였다. 학교라는 유형의 공간을 얻기 위하여 무형의 전통을 파괴하기는 쉽지 않았기 때문이었다. 그러나 CAI는 이러한 조건들을 최소 한의 협력적 관계를 위한 토대로 인식하게 했으며, 지역주민들과 쌓은 신뢰, 그리고 긴 시간동안 의 담화와 논의를 통해 합의점을 찾고자 했다. 적어도 학교를 요구한 것은 지역사회였을지는 몰 라도, 학교를 통하여 지역사회가 어떻게 참여하고 이를 통하여 어떤 방향의 성과를 얻고자 하는 가에 대해서는 CAI와 협력적 관계에 두도록 했던 중요한 원칙이었다. 
넷째, 해당지역 출신 전문가 육성 원칙. CAI는 모텐슨이라는 개인에게서 시작되었다. 탄자니아 에서 의료선교활동을 하는 부모를 둔 그는 다양한 언어를 쉽게 익히고 낮선 환경에 잘 적응하는 체질이 있었다. 따라서 그는 사업 사업초기부터 지역언어를 써서 교육사업을 추진했다. 그러나 $\mathrm{CAI}$ 의 일에서 흥미로운 것은, 모텐슨의 능력에 온전히 의지하는 것이 아니라, $\mathrm{CAI}$ 현지 지부를 만들고 지역 상황에 밝고 적극적인 사람들을 고용하여 CAI 사업을 추진하도록 한 점이었다. 이를 위하여 이들에게 전문적인 사업형성-사업기획-사업추진-사업평가 역량을 키운 것은 물론, 전 통적 문화에 안주하지 않고 근대적 교육발전을 인식할 수 있도록 역량을 키우도록 했다. CAI 현 지 지부는 국제개발협력에서 그리 새로울 것은 없지만, 현지 지부의 핵심적인 사업형성 및 사업 추진이 본부파견 인력이 아닌 현지 지역민들 중심으로 이루어진다는 것은 사례를 찾아 보기 쉽지 않다. 사회, 문화, 정치적인 이슈들이 예민하게 다루어질 수밖에 없는 곳에서 이들의 역할은 클 수밖에 없었으며, 현지어를 구사할 수 있는 덩치 큰 외부인의 낮섦과 거리감 없이 사업을 추진할 수 있었다. 실제 CAI는 산악지역의 여아들을 위한 교육사업이 자신들과 거리가 먼 외지인들의 ‘ 특별한 국제 프로젝트'가 아닌 '자신들의 일’로 인식하게 하였고, 이를 통하여 사업의 효과성을 극 대화하고자 했다.

다섯째, 누구의 손길도 닿지 않는 곳을 찾는 원칙. 국제개발협력사업의 난점은 투입한 재원의 성과를 가시적으로 확보하기 쉽지 않다는 것이다. 따라서 2005년 파리선언 이후 원조효과성을 논 의하고 사업의 책무성을 엄격히 하는 성과기반 평가가 주목을 받고 있다. 따라서 가시적인 성과 를 위하여서 사업이 처할 수 있는 위험을 최대한 줄여야 하며, 결국 안전이 보장된 장소와 네트 워크에서 사업을 진행할 수밖에 없다. 그러나 CAI의 경우에는 이러한 일련의 국제개발협력의 태 도와는 일치하지 않는 길을 걸었다. CAI는 학교를 짓되 누구도 지으려하지 않거나, 혹은 짓더라 도 가장 나중에 지을 것 같은 장소를 골라 다녔다. 물론 이러한 장소에서 학교를 지어달라는 요 구를 했다는 전제하에서 일이 이루어졌다. CAI의 활동이 알려지면서 파키스탄 정부는 모텐슨에게 국가훈장을 수여하고, 산간지역이 아닌 도심과 인근지역에 학교를 지어달라고 요구했다. 그러나 $\mathrm{CAI}$ 는 이 요구를 거절하고, 다시 산간지역으로 올라갔다. 당장 총알이 날아다니는 전장이 아니라 면 $\mathrm{CAI}$ 는 교육의 요구는 모든 이들의 요구이고 이를 통하여 미사일보다 더 강한 평화 정착의 수 단이 될 것이라고 믿었다. 당장 특별한 변화가 일어나기 어렵다는 것을 분명하게 인식한다고 하 더라도, 학교와 학교에서의 짧은 교수-학습이 전혀 다른 세대를 길러내고, 이들의 세계관을 바꾸 어갈 것이라 본 것이다. 이는 누구도 신경 쓰기 어려운 곳에서부터 시작해야 한다고 보았다. 나머 지는 굳이 CAI가 아니더라도 지원을 받아 교육여건을 마련할 수 있다고 보았기 때문이었다. 


\section{나. BLG 구상에의 함의}

CAI는 여전히 히말라야 산지의 이슬람 문화권 공동체와 협력하여 교육권 강화를 위한 사업을 진행하고 있다. 학교짓기를 넘어서서 최근에는 여아들의 중등학교 진학을 위한 장학사업, 지역사 회 여성들의 수입창출을 위한 직업기술교육, 문해교육 등을 포괄적으로 시행하고 있다. 또한 교육 과 관련된 공중보건교육 등을 연계하고 있다. 그러나 결코 문화적 정체성에 도전이 될 만한 주제 를 다루거나, 이들의 생활방식을 부정하게 하는 사회, 문화, 정치적 활동은 금하고 있다. 앞서 제 시한 다섯 가지의 원칙, (1) 세 잔의 차 원칙, (2) 교육 이전의 우선 해결과제 원칙, (3) 지역사회의 요구에 의한 사업의 시작, 지역주민에 의한 학교 운영 원칙, (4) 해당지역 출신 전문가 육성 원칙, (5) 누구의 손길도 닿지 않는 곳을 찾는 원칙을 토대로 BLG 구상의 향후 추진 방향에 대한 간단 한 제언을 덧붙이고자 한다.

첫째, 교육은 보수적인 전통사회에서 문화적 정체성을 훼손하게 할 수 있는 도전적인 영역으로 인식된다. 특히 여아, 여성청소년, 성인 여성을 대상으로 한 교육은 문화적 정체성의 훼손과 함께 사회정치적 권력관계의 변화를 도모한다는 인식을 갖게 할 수 있어 금기시되고 있다. 비록 사회 의 특성에 따라 이러한 억압과 금기의 수준이 다르고, 교육이 미칠 수 있는 도전적인 영향력에 대해 인식하는 수준이 다를 수 있다고 하더라도 개발도상국의 여성들은 여전히 사회, 문화, 정치, 경제적인 측면에서 차별과 편견의 대상으로 자리하고 있다. 따라서 BLG 구상은 적어도 개발도상 국의 여아들에게 교육의 기회를 부여하고, 양질의 교수-학습 환경을 만들어준다는 호의적인 지원 을 한다고 생각해서는 안된다. CAI는 학교 하나를 짓기 위해 꽤 오랜 시간 그 지역에 학교 짓는 것이 정말 필요한 일인지에 대해서 회의를 갖는다. 그리고 지역사회의 모든 원로들과 이해당사자 들의 이야기를 듣는다. 만약 이 과정에서도 합의되지 않는 것이 있다면, 합의가 이루어질 때까지 논의를 갖거나 혹은 CAI 담당자들은 지역사회 논의에서 빠져 지역사회 내에서 문제를 해결할 때 까지 기다린다. 적어도 BLG 구상은 단순히 학교교육의 기회를 확대하자는 차원의 문제가 아니라 는 점, 따라서 그들의 문화와 사회정치적 관계들을 충분히 고려하기 위한 시간과 관계형성을 위 해 노력해야 한다.

둘째, CAI가 가졌던 원칙처럼 BLG 구상의 내용들은 지역사회/공동체의 요구에서 시작하여 추 진되어야 한다. 지금까지는 양자간 협력에 근거하여 국가와 국가간의 요구와 합의를 근거로 대규 모 프로젝트나 프로그램이 추진되어 왔다. 그러나 여아들의 교육을 위한 논의는 민감한 이슈들을 포함할 수밖에 없다는 점에서 한국 측의 요구와 타당성조사가 아닌 해당 국가/지역의 요구와 사 업형성을 지원하는 방식으로 추진되는 것이 필요하다. 단, 한국은 BLG 구상에 분명한 사업의 방 향 및 성과를 위한 조건을 내걸어야 한다. 즉, 사업을 요구한 지역사회/공동체가 책임을 지고 사 
업의 처음과 과정을 통제하고 관리할 수 있도록 해야 한다. 가능한 한국은 협력자로 그들을 신뢰 하는 정도의 선을 넘지 않는 것이 필요하다.

셋째, 해당 지역의 전문가들을 최대한 활용하고, 그들의 교육사업 운용역량을 키우기 위해 노 력해야 한다. 어쩌면 BLG 구상을 위하여 중점지원대상국가의 여아-여성청소년-성인 여성 교육 전문가들을 한국에 모아 전문적인 워크샵을 열고 그들의 의견을 청해 듣는 것이 필요할지 모르겠 다. 또한 국제사회에서 이미 이 지역에서 행해진 교육권 강화사업의 이행 실적과 성과들을 재검 토해보고, 한국의 지원과 협력이 어떠한 차별적 성과를 만들어낼 수 있는지 해당지역의 전문가들 을 통해 확인하는 절차가 필요할 것이다. 만약 이들이 한국의 BLG 구상을 체화하고, 보다 효과 적인 프로그램을 성안하고 추진할 수 있게 된다면, 한국은 이들을 통해 국내 전문가들을 훈련할 수 있고, 또한 지역전문성 또한 갖추도록 시스템화할 수 있을 것이다.

넷째, 능력 있는 여아 교육자들을 길러내야 한다. 여아와 여자 청소년들에게 직접적으로 교육 권을 강화할 수 있는 환경을 만들어주고, 이들에게 필요한 인프라, 기자재, 그리고 프로그램을 마 련해주는 것이 중요하겠지만, 오히려 이들에게 영향을 미칠 수 있는 교육자들을 길러내는 것이 보다 파급력 있는 방안이 될 수 있다. 따라서 사업의 전체 비중 중 일부를 여아 교육과 이들의 교 육지원을 위한 현지 교육가들을 양성할 수 있는 시스템에 투자하고, 이를 통하여 지속적으로 교 육가들이 양성될 수 있도록 지원하는 것이 필요하다.

다섯째, 이미 BLG 구상을 위한 중점지원국가들이 선정되어 있지만,3) 정말 여성교육이 미미하 고, 영아 시기부터 성차별과 편견, 문화적 억압이 구조적으로 자리잡고 있는 지역에 대한 지원이 이루어질 수 있도록 재고해 볼 필요가 있다. CAI가 가장 먼 곳, 결코 국가에서 지원하겠다고 하 기 어려운 곳을 일부러 택해 갔던 상황을 염두에 둘 필요가 있다. BLG 구상은 적어도 국제사회 의 성평등을 위한 중요한 토대가 여아들의 교육과 신체적 건강에 있다고 믿는만큼, 이러한 기회 가 다른 어느 곳에서도 미치지 않는 곳을 찾아가야 하리라 생각한다. 적어도 CAI가 그 지역의 사 회 문화 정치, 경제적 이해관계에 있어 완전히 자유롭게 행동했던 것처럼, BLG 구상의 내용과 주체들 또한 국가와 국가간의, 이념과 이념간의 갈등과 긴장에서 자유롭게 지원하고 협력할 수 있도록 마련되어야 할 것이다.

3) BLG 구상을 구체화하기 위한 중점사업국은 아시아 6 개국(네팔, 라오스, 캄보디아, 방글라데시, 스리랑카, 필리핀), 아프리 카 6 개국(에티오피아, 세네갈, 우간다, 코트디부아르, 모로코, 탄자니아), 중동(요르단), 중남미 2 개국(볼리비아, 에콰도르) 등 총 15 개국으로 정해져있다. 


\section{V. 결론}

'세계 여성의 날(매년 3월 9일)은 전세계의 억압받는 여성들의 삶의 여건을 살피고, 한 인간으 로서 누려야 할 마땅한 권리와 자유로운 삶의 선택을 위한 환경개선을 옹호하기 위해 제정되어, 기념되고 있다. 여성으로서의 삶이 갖는 사회구조적 구조가 불공정하고 억압적이라면 이를 드러 내고 개선해 나가기 위한 노력이 필요하다. 사회 발전에서 당연한 과정이라고 여겨지지만, 실제 이러한 일은 절대 그냥 일어나지 않는다. 2014년 노벨 평화상을 공동 수상한 '말랄라'의 경우, 이 러한 문제를 해결하기 위한 가장 큰 방책으로 교육을 주장했고, 실제 교육을 통해서 파키스탄의 여성 삶의 질이 개선될 수 있음을 보여주었다. 그러나 사회를 변혁시켜가야 하는 역할로서 교육 의 중요성을 강조하는만큼 교육은 전통적인 사회문화적 질서를 유지하고, 보존하며, 기존 사회구 조를 온존시키고자하는 반동적인 기능을 수행한다. 따라서 교육이 듣기좋은 수사적인 표현 이상 의 실질적인 사회변화의 힘을 발휘하기 위해서는 교육의 기회를 받지 못했고, 교육다운 교육의 기회에서 소외되었던 사람들의 교육기회를 확대해야 한다.

국제사회는 함께 실현해야 할 '지속가능한 발전'의 핵심 과제로 교육을 내세윘고, 이를 달성하 기 위한 공동의 협력과 노력을 요청하고 있다. 이번 BLG 구상은 이러한 국제사회의 요청에 부응 하는 적절한 계기가 될 것이며, 무엇보다 앞서 언급한 바와 같이 스스로 변화하기 어려운 사회문 화적 조건에 작은 변화의 씨앗을 뿌리고 키우는 역할을 하게 될 것이다. BLG 구상이 지금까지의 의례적인 일방적 원조로서의 교육개발협력을 벗어나 보다 상호교호적이고, 쌍방향 소통적이며, 보다 사회변혁적인 방식으로 기능하도록 해야 할 것이다. 본문에서 제시한 바와 마찬가지로 국가 와 국가 간의 거시적인 정치-외교적인 이해관계를 넘어서서 실질적인 수혜자가 될 여아와 여성 청소년들의 삶을 중심으로 지원이 이루어지도록 해야 한다. 하늘 아래 인구의 반 이상을 차지하 는 동등한 인격의 소유자로, 사회경제적 조건에 상관없이 스스로의 삶을 개척하고 이를 위한 선 택의 자유를 누릴 수 있도록 교육권 강화가 이루어질 수 있기를 기대해본다. 


\section{〈참고문헌〉}

그렉 모르텐슨, 데이비드 올리버 렐린. 2009.『세 잔의 차』. 서울: 도서출판 이레 니콜라스 크리스토프, 쉐릴 우던. 2010. 『절망너머 희망으로』.서울: 에이지 21 말랄라 유사프자이, 크리스티나 램. 2014. 『나는 말랄라』. 서울: 문학동네 유성상. 2015. "EFA와 Post 2015 글로벌 교육의제: WEF의 성과와 한계, 그리고 과제". 한국평생교육학회 2105년도 연차학술대회(10월 18일, 제주대학교)의 심포지움 발표자료 한국국제협력단. 2015a. '소녀들의 보다 나은 삶 구상' KOICA 뉴스레터 (2016년 1월), http://webzine.koica.go.kr/201601/content.php?code=201601_010315 2015b. "KOICA 교육분야 전략(2011-2015)” 미발간 보고서. 성남: 한국국제협 력단

Mortenson, Greg. 2010. Stones into Schools: Promoting Peace with Books, Not Bombs, in Afghanistan and Pakistan. New York: Penguin books 